\title{
The Relationship between Media Literacy and Listening Comprehension among Iranian Intermediate EFL Learners
}

\author{
Abbas Ali ZAREI ${ }^{1}$, Parisa PARHIZKARI ${ }^{2}$ \\ ${ }^{1}$ Associate professor, Imam Khomeini International University, Qazvin, Iran \\ E-mail: a.zarei@hum.ikiu.ac.ir \\ ${ }^{2} \mathrm{MA}$, Imam Khomeini International University, Qazvin, Iran. \\ E-mail: Paricsa. Parhizkari@gmail.com
}

\begin{abstract}
This study aimed to investigate the relationship between media literacy and listening comprehension among Iranian intermediate EFL learners. To this end, after conducting Michigan Test of English Language Proficiency (MTELP), 84 Iranian EFL learners at intermediate levels of English language proficiency were selected. Then, the media literacy questionnaire (Media Literacy Self-assessment Scale (MLSS)), developed by Chang et al. (2011), with 13 items and a listening comprehension test (TOEFL Listening: Lecture (1) (2015)) with ten multiple-choice questions was used to measure the learners' media literacy and their level of listening comprehension ability. To test the possible correlation between media literacy and the learners' listening comprehension, the Pearson correlation coefficient was used. The findings revealed that there was a positive relationship between media literacy and listening comprehension.
\end{abstract}

Keywords: Media Literacy, Listening Comprehension, Iranian Intermediate- Level EFL Learners

\section{Introduction}

Listening is age old. It has always been a crucial part of interaction. It is not just hearing the other side, but through the message, having an agreement or giving the right answer with the aid of grammatical and pragmatic knowledge understanding the speakers' accent or pronunciation, grammar, vocabulary, and grasping meaning (Yavuz et al, 2015). Listening is one of the most vital and pivotal skills in language. It enables language learners to receive input and facilitates the emergence of other language skills (Vandergrift \& Goh, 2012). Until recently, it was unjustly neglected by researchers and educational administrators, and it was considered as a passive skill (Khalili Sabet \& Mahsefat, 2012). That is why Nunan (1997) calls it the Cinderella skill in second language learning.

One of the influential factors in English language teaching in general and the listening skill in particular is media literacy. In today's society, factors such as the growth of informational and 
communicational technology, the advent of mass media and new educational policies have made media literacy a focus of research (Bektas, 2009). Buckingham (2005) asserts that media literacy is a highly multifaceted and often debated term; his definition of media literacy is based on the definition of Ofcom (an institute in the Uk) as "the ability to evaluate, understand and create communications in different contexts and refers to both older media channels such as television, radio, print media and new media such as Internet, mobile cell-phone and video games" (p.3). The users of both old and new media need various kinds of literacy such as traditional literacy, media literacy, and new media literacy. New media literacy integrates traditional media literacy with new elements of basic computer technology expertise coupled with interactive communication skills. Basic knowledge of English is an essential requirement for using new media technologies. This new literacy constitutes a prerequisite for the utilization of the latest digital technologies (Adoni \& Nossek, 2001).

The present study is an attempt to investigate the relationship between media literacy and listening comprehension of Iranian EFL intermediate learners. It focuses on the following research question:

Is there any significant relationship between Iranian EFL learners' media literacy and their listening comprehension?

\section{Literature Review}

\subsection{Listening Comprehension}

Listening is a crucial means of acquiring second or foreign languages, not just a skill in language performance (Carter \& Nunan, 2001). Listening, as a key skill in language for its vital role in language acquisition and learning, has been a cornerstone of many theories (Flowerdew \& Miller, 2005). There are various definitions for listening. Some researchers define listening as encompassing four processes: receiving, attending to, assigning meanings to, and responding to information (Buck, 2001; Rost, 1994; Rubin, 1994; Wolvin \& Coakley, 1996). Definition offered by O`Malley, Chamot and Kupper (1989, p.19) is more extensive than others; they define listening comprehension as "an active and conscious process in which the listener constructs meaning by using cues from contextual information and from existing knowledge while relying upon multiple strategic resources to fulfill the task requirement".

There are two main kinds of listening: intensive and extensive. In intensive listening, learners should understand the meaning of each discourse and ultimately to understand every sentence and word. The goal of intensive listening is to build fundamental listening skills. In extensive listening, the general meaning of the passage should be grasped by the learners. The goal of this kind is to strengthen and enlarge the effectiveness of intensive listening in order to improve overall listening ability. (Pourhossein Gilakjani \& Ahmadi, 2011). Critical listening is an example of intensive listening, which involves interpretative, introspective, responsive, and productive listening and evaluative events (Brown, 2004; Tarigan, 1990). Interactive listening is 
another type of listening, which is the listeners' capability to interact with target language speakers in social situations such as conversations. In interactive listening, the role of second language listeners and speakers are changed. The aim of this type of listening can be transactional, interactional or purely social to foster social relationships (Vandergrift \& Goh, 2012).

Moreover, there are two steps in listening comprehension process. Receiving, memorizing and repeating the sounds are involved in the first step. The second step, which is the comprehension step, includes the ability to explain the content of the message that is exposed by the speaker (Zhang, 2001). The second step requires learners to engage in different complicated tasks from discriminating sound to understanding the speaker's message (Coskun, 2010). Rost (2011) points out that there are four processes in listening, including receptive, constructive, collaborative, and transformative. There are also five stages of hearing, understanding, remembering, evaluating, and responding in listening process (Tyagi, 2013). There are also two types of reciprocal and nonreciprocal processes in listening (Brown, 2011).

The role of listening is significant in language learning, but it is still an area where learners feel most powerless and disappointed (Taghinezhad, Tabaeifard \& Bazyar, 2015). Ghaderpanahi (2012) asserts that among the four language skills, listening is the slightest accurate one, so it is the hardest skill to acquire. It is a very complex process and most learners have serious problems in using it (Lynch, 1998; Vandergrift \& Goh, 2012). Bingol, Celik, Mart and Yildiz (2014) assert that there are some potential problems in language learning classes including cultural differences, accent, unfamiliar vocabulary of physical conditions, lack of concentration, length, and speed of the listening. Underwood (1989) asserts that seven obstacles to efficient listening comprehension are: inability to control the speed, inability in word repetition, having limited vocabulary, inability in recognizing the signals, lack of contextual knowledge, listeners' lack of concentration in a foreign language, and some wrong learning habits. Brown (2011) adds text, task, speaker, and listener as additional causes to listening problems.

There are some solutions which help listeners get rid of these problems, 1) making leaners aware of their purposes for listening. In other words, presenting listening for main ideas; listening for details; listening and making inferences (Brown, 2011; O’Mally \& Chamot, 1990), 2) using different tasks such as: using micro-skills, using video and multimedia, going beyond conversations and providing opportunities to listen to extended prose, dictation, and encourage extensive listening (Brown, 2011).

In addition, a subject which has a significant role in listening is listening instruction. There are different kinds of listening instruction. In text-oriented instruction, emphasis is on recognizing and understanding different components of listening input. These include individual sounds and phonological features as well as key words and phrases. An explanation for this emphasis is found in the early ideas of cognitive psychology. In communication-oriented instruction, teachers use authentic materials such as songs, movies and recorded conversations for listening. Learner-oriented instruction involves teaching learners how to listen; one 
instruction gap is the lack of guidance on how learners can self-direct and evaluate their efforts to improve their listening (Vandergrift \& Goh, 2012). Learners' self-regulated learning is the result of metacognitive instruction (Pintrich, 2000). Meanwhile, repetition is good for comprehension (Chang \& Read, 2006; Iimura, 2007; Sakai, 2009).

The environments of language learning have moved into a new era of teaching listening with the advent of technology. This movement was based on the use of authentic audiovisual materials (Vandergrift, 2011). Nowadays, technologies for listening development have been developed from audio recordings to visual media. By adding visual components to listening instruction, the authenticity of classroom listening material increases. When learners watch the speaker, in addition to listening, they have the option to attend to potentially helpful cues known as spelling problems that can facilitate the interpretation of a message. (Vandergrift \& Goh, 2012).

Authentic materials offer real language and its usage in the community (Kilickaya, 2004). This term is a "positive attribute, collocating with desirable qualities such as purity, originality, and quality" (Mishan, 2004, p. 219). Among many advantages of authentic materials are increasing learners' motivation, offering useful cultural knowledge, providing real language, noticing learners' future needs and supporting creative teaching (Richards, 2001).

Ghaderpanahi (2012) studied the role of authentic materials in the listening of EFL learners in Iran. The findings revealed that students' listening comprehension in class improved more than their comprehension outside the classroom, where certain authenticity features such as pace, accent, and dialects could impede comprehension.

Ghalami Nobar and Ahangari (2012) explored the effect of computer assisted language learning (CALL) on improving Iranian EFL learners' task-based listening as a motivating device to enhance positive attitudes. The findings indicated a significant difference between the experimental and control groups.

Behroozizad and Majidi (2015) investigated the effect of different modes of English captioning on EFL learners' general listening comprehension. The findings showed significant differences among full captions, keyword-captions, and no-captions in terms of their effect on learners' general listening comprehension.

Hayati (2010) examined the impact of speech rate on listening comprehension of Iranian EFL learners. The findings showed that each speech rate, whether natural or slow, could improve EFL learners' listening comprehension; however, natural speech rate had greater effects than slow speech rate on EFL learners' listening comprehension.

\subsection{Media Literacy}

Media literacy is a very rich and multifaceted term. Every medium, genre and topic covered by the media is concerned with media literacy (Rosenbaun, 2016). Some researchers consider media literacy as an umbrella term which can be defined as the ability to access, analyze, evaluate and 
communicate in different forms of media (Considine, Horton \& Moorman, 2009; Livingston, 2004). Media literacy focuses on knowing how media messages are constructed and received. It involves an awareness of one or more characteristics of using media and production of media messages (Rosenbaun, 2016). Media literacy is a critical viewing skill and competency to regard, examine, understand, and interpret the ways in which different media produce meaning (Abdullah, 2000; Covington, 2004).

Knowledge, skills and attitudes are three determinant factors in media literacy. In some studies the notion of media literacy was reflected as 'knowledge' (Messaris, 1998; Potter, 2004; Silverblatt, 1995); in these studies knowledge was defined in terms of 'structures' of how to deal with media. Moreover, the key determinant of media literacy is skill, which includes instrumental/operational, structural/informational and strategic skills. Instrumental and operational skills are fundamental skills needed to access and employ the technology; Structural and information skills include essential skills needed to deal with the new formats through which information is passed, in the other word, they are needed skills to know what is essential, search it, find it, evaluate it and employ it; Strategic skills are those skills needed to acquire knowledge about the media and employing it for personal purposes (Steyaert, 2000; Van Dijk, 2005). Furthermore, people's attitudes are also determinant factors in media literacy (Brandtweiner et al., 2010).

Media literacy has expanded to new media literacy. So, new literacies are built on the basis of traditional literacy and print culture (Barden, 2011; Jenkins, et al, 2009). They include social skills, research skills, technical skills, and critical developments through collaboration and networking (Barden, 2011). The New Media Consortium (NMC) is an international community of experts in educational technology, which was founded in 1993 by a group of hardware manufacturers, software developers, and publishers. NMC (2005) defines twenty- first century literacy as a set of capabilities and skills where visual, aural, and digital literacy overlap. This new literacy encompasses the power of sounds and images, identifying and employing that power, managing and transforming digital media, distributing them pervasively, and modifying them to new forms easily.

With the advent of new technologies, traditional literacy is no longer sufficient for an individual in order to competently survive in this new media ecology ( $\mathrm{Lin}, \mathrm{Li}$, Deng \& Lee, 2013). Jenkins, et al (2009) assert that new media literacies are new ways of processing culture and interacting within a larger community which is developed through collaboration and networking, and not simply as individualized skills to be employed for personal expression.

According to Rosenbaum (2016), media literacy is intertwined with people's daily life. The proponents of media literacy argue that just as people need to learn how to read alphabet, they also should learn how to read the media. Today, without the use of multiple techniques based on modern computers and innovations of 'digital' pedagogy, effective teaching and learning is impossible. One of UNESCO's main goals in education, which offers high quality and accessible informational resources for all people, is achieved through the combination of social media and 
open educational resources. It plays an essential role in both learners' individual and social life (Rosenbaum, 2016).

Media literacy can facilitate the development of critical thinking skills; it satisfies learners' intellectual curiosity and even can change their perspectives on life (Chang, et al, 2011). It is vital to manipulate new technologies and for the ability to interpret and process media messages which, in turn, influence today's life (Thoman, 2003). For example, Web 2.0 tools are one of the places where media or new literacies are needed. The shift to Web 2.0 tools can have a deep effect on schools and learning; it also causes a transformation in thinking. This will happen because the tools enhance creativity, collaboration, and communication and they fit with learning methods in which these skills are integrated (Solomon \& Schrum, 2007).

One aspect of new media literacy is the knowledge of learners about the validity and reliability of online information, ethical aspects, and copyright law. Andresen and Brink (2013) argue that regarding easy usage of technologies, especially Web 2.0, more and more people are able to create information in different fields of science. So, there is no systematic quality assurance of the validity and reliability of data. The only way of assurance is that the users are critical in order to identify incorrect data and attempts at manipulation. Teachers and learners should be aware of ethical aspects and focus on them. These aspects include copyright, plagiarism, quantitative conceptions, and qualitative conceptions.

One way to prepare learners for the literacy they deserve in the future is the integration of media literacy and technologies (Larson, 2008). Another way is that adolescents learn how to integrate knowledge from various sources of information. These sources including video, music, online databases, and other media. The other way is learners' familiarity with six categories of individuals' competencies in media literacy such as, self-reflective competencies, effective competencies, social-reflective, practical knowledge, technical knowledge, creative skills in using media (Gapski, 2001). Still another way is promoting media literacy. To reach this goal, some means are essential. Means such as print literacy education, public understanding of science and health promotion which support educators to increase media literacy among people (Livingstone, 2004).

Prensky (2001) argues that today's learners are digital natives because they have access to digital technology display features such as digital fluency and familiarity with new technologies which never before were imaginable. A range of activities should be identified by teachers and administrators for using in schools or after school programs to cultivate these social skills and cultural competencies (Jenkins et al, 2009).

There are many studies on the relationship between media literacy and language learning. Dvorghets and Shaturnaya (2015) investigated the idea of developing students' media literacy in English language teaching contexts. This study was done to examine the idea of developing students' media literacy through integrating English and American mass media resources into the English classroom. The findings of this research also showed significant improvement of the students' critical thinking ability and media literacy. 
Karadeniz and Can (2014) investigated the book reading habits and media literacy of students at the faculty of education in terms of various variables. The findings showed that the attitudes of female learners towards reading are higher than those of male learners. While there were positive correlations among the reading habits, media literacy and grade point averages, there was a negative correlation between the reading habits and social media using habits.

Meihami, Meihami and Varmaghani (2013) examined the effectiveness of CALL materials on the listening comprehension of Iranian learners. The findings of their study showed that using CALL material can enhance Iranian EFL students' listening comprehension.

Fardy, Noori Shorabi and Mohammadi (2012) investigated the effect of using computers and internet on improving EFL learners' listening comprehension skill and motivation. The results revealed that the use of the computer had an important role in the improvement of EFL learners' listening comprehension.

Hasan and Hoon (2012) in their research investigated that podcasts motivate learners towards learning English and improve their language skills, especially listening. Kargozari and Tafazoli (2012) studied the relationship between podcast and Iranian EFL learners' listening ability. The results of their study indicated that podcasts were efficient to improve listening ability and generated a feel of satisfaction and confidence among the learners. A research by Ashraf, Noroozi and Salami (2011) on the using of podcast as listening material came to the conclusion that podcasts can be used to develop the listening skill of language learners.

\section{Method}

\subsection{Participants}

In the present study, the researcher selected a sample of 120 male and female Iranian B.A. level undergraduate students majoring in Teaching English and English Translation at Imam Khomeini International University in Qazvin. The participants included 68 females and 52 males, all of whom were between the age ranges of 21 to 26 . Of these participants, 5 did not fully participate in the study; 17 did not answer at least one of the questionnaires, and 14 participants were excluded from the study because of extremely high or low levels of proficiency measured with the Michigan Test of English Language Proficiency. Therefore, the final number of the participants was 84 .

\subsection{Instruments}

In this study, the following data collection instruments and materials were utilized:

1) The Michigan Test of English Language Proficiency

2) A media literacy questionnaire

3) A listening test 


\subsubsection{Michigan test of English language proficiency (MTELP)}

The Michigan Test of English Language Proficiency (MTELP) contained 100 items in three sections: grammar, vocabulary, and reading comprehension. There were 40 items on grammar, 40 items on vocabulary, and 20 items on reading comprehension. To check the reliability of the test, the KR-21 formula was used, and the reliability index turned out to be .79 .

\subsubsection{Media literacy questionnaire}

The media literacy questionnaire (Media Literacy Self-assessment Scale (MLSS)), developed by Chang et al. (2011), with 13 items, was used to measure the students' media literacy. Chang et al. (2011) have reported an alpha coefficient of 0.9 for the questionnaire. The MLSS consists of three subscales, presented with agree/disagree statements on a five point Likert type scale from 1 $=$ Strongly Disagree, to $5=$ Strongly Agree. A detailed description of these three subscales is as follows: 1) 6 items were about Media Application Skills subscale (MAS), which assessed learners' ability to perform media technologies, 2) 7 items were about Learning with Media subscale (LWM), which assessed students' ability to extract messages from media to perform learning tasks, 3) 5 items were about Attitudes toward Media subscale (ATM), which assessed students' perceptions regarding the copyright ethics of technology (Chang \& Liu, 2011).

\subsubsection{Listening Test}

To measure the participants' listening comprehension, the researcher used an academic lecture (TOEFL® Listening: Lecture (1) (2015)), which offered the biography of Sylvia Plath, an American famous woman. This test consisted of ten multiple-choice questions designed to measure the level of listening comprehension ability. Learners were asked to listen to the audio text twice and select the correct answer. The reliability of this test was estimated by the researcher through KR-21 formula, and the result turned out to be .95 .

\subsection{Procedure}

The researcher followed the following procedure in order to achieve the purpose of the present study. Initially, the participants were selected based on availability and cluster sampling from among undergraduate students majoring in Teaching English and English Translation at Imam Khomeini International University in Qazvin.

In order to homogenize the participants, the researcher used the MTELP. She administered it at the beginning of the study to make sure that there was no difference among the participants in terms of their proficiency level. The students were given 100 minutes to complete this test. Then, the researcher selected the students whose score was less than one standard deviation away from (above or below) the mean, and excluded the rest from all subsequent analyses. 
In the second stage, the homogeneous students were offered the media literacy questionnaire and asked to answer the questions. The students were given 13 minutes to answer the media questionnaire.

In the last stage, the listening test was administered to all the participants. The students were asked to listen to the listening test twice. For the first time, there was no question and the participants just carefully listened to the audio. Then, the test papers were given to the participants, and they had 5 minutes to read the questions. After that, the listening text was played again and when it finished, the participants had 13 minutes to answer the test.

\section{Results and Discussion}

\subsection{Investigation of the research question}

The research question sought to investigate the relationship between Iranian EFL learners' media literacy and their listening comprehension. To answer this question, the researcher used Pearson product-moment correlation to investigate the correlation between these two variables.

The analysis of the data showed that Pearson correlation coefficient between media literacy and listening is $(\mathrm{r}=.59, \mathrm{p}<.01)$. This suggests that there is a positive relationship between these two variables. So, the null hypothesis is rejected. The result of the correlation between these two factors is shown in Table 4.1.

Table 4.1: Pearson Correlation between Media Literacy and Listening

Media literacy

Listening

\begin{tabular}{cccc}
\hline \hline Media literacy & Pearson Correlation & 1 & $.595^{* *}$ \\
\hline \hline & Sig. (2-tailed) & & .000 \\
\hline \hline $\mathrm{N}$ & 84 & 84 \\
\hline \hline
\end{tabular}

**. Correlation is significant at the 0.01 level (2-tailed).

\subsection{Discussion}

The present study attempted to investigate the relationship between media literacy and Iranian EFL learners' listening comprehension. The findings of the present study indicated a positive correlation $(\mathrm{r}=.59)$ between media literacy and listening comprehension. Many studies have been 
done on the relationship between new media technologies and EFL listening comprehension as well as on the relationship between social networks and EFL listening comprehension. However, the researcher could not find a study exactly similar to her own measuring the relationship between media literacy and EFL listening comprehension. However, as mentioned earlier, media literacy is vital for using new media technologies and social media, which, in turn, are effective on English learning in general and listening, in particular. From that perspective the finding of the present study supports that of Karadeniz and Can (2014), who reported a positive correlation between reading habits, grade point averages and media literacy.

The result of the present study is also consistent with Arono's (2014) finding that interactive multimedia is effective on improving students' critical listening skill. In addition, the finding of the present study supports Pourhosein Gilakjani's (2012) finding that multimedia instruction creates the opportunity for students to improve their learning effectively. The result of the present study is also in line with that of Ahmad (2012), who reported the positive effect of the integration of media technology in English language teaching, especially on improving accentual patterns of individual English words. Moreover, the finding of the present study lends support to Ghalami Nobar and Ahangari's (2012) finding suggesting that the use of computer has a significant role in the improvement of EFL learners' listening comprehension. It is also consistent with Basaran and Cabaroglu's (2014) finding, based on which there was a significant difference in participants' perceptions of their listening comprehension, speaking, and reading skills and also their writing self- efficacy after they experienced e-learning.

Moreover, the finding of this research is in line with Dey's (2014) finding, which indicated that podcast can motivate learners to develop their listening skill. It is also consistent with the finding of Shiri (2015), who reported that podcasts have an effect on improving learners' motivation for listening. In addition, the finding supports those of Silviyanti (2014), who asserts that the employment of YouTube is beneficial and interesting for learners in a listening class.

Furthermore, the finding of the present study supports Ismaili's (2013) finding, which indicated that movies have significant impact on developing students' listening and communication skill. The finding is also in line with Karimi and Biria's (2014) finding, based on which visuals as a motivating factor, improve Iranian EFL learners' listening comprehension.

In addition, the finding of the present study is in line with those of Saran and Seferoglu (2010), who assert that in mobile learning, employing MMS and SMS is effective on improving vocabulary knowledge. The result is also consistent with Begum's (2011) finding indicating that cell phone has great potential as an instructional tool. It is also in line with Ketabi, Zarei and Khazaie's (2011) finding, based on which mobile learning (m-learning) is effective in the context of teaching English vocabulary to Iranian semi-illiterates.

On the other hand, this finding of the present study contradicts that of Chen and Zhang (2011), who reported that the Web-based CALL does not improve listening comprehension. 
A number of factors could possibly account for these finding. One of the reasons may have been the number of learners. There were 84 participant in this study, while the number of participants in the study by Eksi and Yakisik (2015) was 383; in Chang and Liu (2011), the number of the participants was 1,500; in Adoni and Nossek (2001), the participants included 2,424 learners. The other possible factor which might have affected the findings of the present study was the participants' multiple intelligences, which was not controlled in this research, while, Mahasneh (2013) reported that students' multiple intelligences were correlated with their listening comprehension. Still another factor which might have influenced the findings of this study was learners' level of proficiency. Intermediate level learners participated in this research, but the participants of Chang and Liu's (2011) study were students of an elementary school. The participants of Begum's (2011) study were undergraduate EFL university students. The participants of Stockwell's (2010) study were pre-intermediate learners of English, and those of Golpour's (2014) study were advanced level EFL students. And also, in the present study, the gender and age of the students were not taken into account. Also, the findings of the present study might have been affected by many other factors such as native language, students' economical condition, cultural background, social factors and so on.

\section{Conclusion}

Based on the findings of this study, it may be concluded that Iranian EFL learners' listening comprehension and their media literacy are closely inter-related, and that the integration of these two can enable learners to develop better understanding of both new media and language. Schmidt (2012) asserts that today it is necessary to aid college students to develop new media literacy competencies, because there are real benefits associated with media literacy in educational contexts, especially in foreign language learning. Zarei and Hashemipour (2015) assert that the integration of technology and educational curriculum can solve demotivational problems in education. Ghalami Nobar and Ahangari (2012) argue that CALL can be effectively employed to increase EFL learners' motivation. Also, employing visuals improves students' motivation (Karimi \& Biria, 2014). According to Hsu, Hwang, Chang and Chang (2013), the use of mobile devices to learn language increase learners' motivation. And based on the studies such as (Ghalami Nobar \& Ahangari, 2012; Secer, Sahin \& Alc, 2015) motivation significantly affects listening comprehension.

Moreover, authentic materials improve learners' true listening ability in English learning (Ghaderpanahi, 2012) for example, using captions for films can improve general listening comprehension (Basaran \& Kose, 2013; Behroozizad \& Majidi, 2015) or using podcast can develop learners listening skill by motivating them easily (Dey, 2014).

Furthermore, education has been influenced rapidly by the arrival of new media technologies, especially computer technology (Chang \& Liu, 2011) and Internet. This development can be challenging for both teachers and students to adapt and to employ their ability to provide increasingly rich opportunities for learning. So, through identifying the role of 
new media literacy in improving listening skills for EFL students, the present study hopes to increase the quality of teaching listening by integrating teaching methods and new technologies in Iran.

So, in order to improve listening comprehension of EFL learners, curriculum designers and teachers should involve authentic materials in the curriculum and reinforce media literacy to make enable the students to use authentic listening materials, because these materials provide enjoyment and enhance motivation, self-efficacy, critical thinking, autonomy, and create student-centered situation in which learners are responsible for their learning. In this way, they can improve listening comprehension of EFL learners.

Hence, in relation to future English learning, the present study suggests ways forward in implementing new technologies such as mobiles in general, and smart phones in particular, in the EFL learners' curriculum. Teachers have the potential to provide a rich learning environment for their students through mobile phones. Facebook, YouTube, podcasts, Vodcasts, games, and online dictionaries are some examples of applications that can be used on mobiles and cell phones which can enrich the learning process, make the learning more enjoyable, and facilitate learners' cognitive achievement.

\section{References}

[1] Abdullah, M., H. (2000). Media literacy [ERIC Digest]. Retrieved July 23, 2015 from htp://www.indiana.edu/ reading/ieo/digests/d152.html

[2] Adoni, H., \& Nossek, H. (2001). The new media consumers: Media convergence and the displacement effect. Communications. The European Journal of Communication Research, 26(1), 59-83.

[3] Ahmad, J. (2012). English language teaching (ELT) and integration of media technology. Procedia - Social and Behavioral Sciences, 47, 924 - 929.

[4] Andresen, B., B., \& Brink, K., V., D. (2013). Multimedia in education curriculum. Published by the UNESCO Institute for Information Technologies in Education 8 Kedrova St., Bldg. 3, Moscow, 117292, Russian Federation.

[5] Arono, A. (2014). Improving students' listening skill through interactive multimedia in Indonesia. Journal of Language Teaching and Research, 5(1), 63-69.

[6] Ashraf, H., Noroozi, S., \& Salami, M. (2011). E-liBstening: The Promotion of EFL listening skill via educational podcasts. Proceedings of the 6th International Conference on E-Learning (ICEL) (pp. 10-17). Oxford shire, UK: Academic Conferences and Publishing International Limited.

[7] Barden, O. (2011). We're superhuman, we just can't spell. Using the affordances of an online social network to motivate learning through literacy in dyslexic sixth-form students. Electronic Thesis. University of Sheffield. School of Education. 
[8] Basaran, S., \& Cabaroglu, N. (2014). The effect of language learning podcasts on English self-efficacy. International Journal of Language Academy, 2(2), 48- 68.

[9] Basaran, H., F., \& Kose, G., D. (2013). The effects of captioning on EFL learner's listening comprehension. Procedia - Social and Behavioral Sciences, 70, 702 - 708.

[10] Begum, R. (2011). Prospect for cell phones as instructional tools in the EFL classroom: A case study of Jahangirnagar University, Bangladesh. English Language Teaching, 4(1), 105-115.

[11] Behroozizad, S., \& Majidi, S. (2015). The effect of different modes of English captioning on EFL learners' general listening comprehension: full text vs. keyword captions. Advances in Language and Literary Studies, 6 (4), 115-121.

[12] Bektas, M., C. (2009). Media literacy courses in faculties of communication in TRNC. Procedia Social and Behavioral Sciences, 1, 446-449.

[13] Bingol, M., A., Celik, B., Mart, C., T., \& Yildiz, N. (2014). listening comprehension difficulties encountered by students in second language learning class. Journal of Educational and Instructional Studies in the World, 4 (4), 1-6.

[14] Brandtweiner, R., Donat, E., \& Kerschbaum, J. (2010). How to become a sophisticated user: a twodimensional approach to e-literacy. New Media and Society, 12, 813-833

[15] Brown, H., D. (2004). Language assessment, principles, and classroom practices. San Francisco: Longman.

[16] Brown, S. (2011). Listening myth. Applying Second Language Research to Classroom Teaching. Manufactured in the United States of America. The University of Michigan Press.

[17] Buck, G. (2001). Assessing listening. Cambridge, England: Cambridge University Press.

[18] Buckinghum, D. (2005).The media literacy of children and young people: A review of the research literature on behalf of OFCOM. Centre for the Study of Children Youth and Media Institute of Education University of London. Retrieved April 12, 2015 from http://stakeholders.Ofcom.org.uk/binaries/research/media-literacy/ml-children.pdf

[19] Carter, R., \& Nunan, D. (2001). The Cambridge guide to teaching English to speakers of other languages. Printed in the United Kingdom at the University Press, Cambridge.

[20] Chang, C., H., \& Liu, E., Z-F. (2011). Exploring the media literacy of Taiwanese elementary school students. The Asia-Pacific Education Researcher, 20 (3), 604-611.

[21] Chang, A., C-S., \& Read, J. (2006). The effects of listening support on the listening performance of EFL learners. TESOL Quarterly 40, 375-394.

[22] Chang, C., S., Liu, E., Z., F., Lee, C., Y., Hu, D., C., \& Lin, C., H. (2011). Developing and validating a media literacy self-evaluation scale (MLSS) for elementary school students. The Turkish Online Journal of Educational Technology, 10 (2), 63-71.

[23] Chen, L., \& Zhang, R. (2011). Web-based call to listening comprehension. Current Issues in Education, 13 (4), 1-24. 
Bulletin de la Société Royale des Sciences de Liège, Vol. 86, special edition, 2017, pp. 891 - 907

[24] Considine, D., Horton, J., \& Moorman, G. (2009). Teaching and reading the millennial generation through media literacy. Journal of Adolescent \& Adult Literacy, 52 (6), 471481.

[25] Coskun, A. (2010). The effect of metacognitive strategy training on the listening performance of beginner students. Novitas-ROYAL (Research on Youth and Language), 4 (1), 35-50.

[26] Covington, W., G. (2004). Creativity in teaching media literacy. International Journal of Instructional Media, 31(2), 119-124.

[27] Dey, S., C. (2014). Authentic Input to Motivate Learners to Develop Listening Skill: Benefits, Drawbacks of Using Podcast. BRAC University, ID -11163006.

[28] Dvorghetsa, O., S., \& Shaturnaya, Y., A. (2015). Developing Students' Media Literacy in the English LanguageTeaching Context. Procedia - Social and Behavioral Sciences, 200, $192-198$

[29] Eksi, G., \& Yakisik, B., Y. (2015). An investigation of prospective English language teachers' multimodal literacy. Procedia - Social and Behavioral Sciences 199, 464 - 471

[30] Fardy, M., Noori Shorabi, H., \& Mohammadi, Y. (2012). The effect of using computerassisted language learning (CALL) on the reading comprehension of narrative texts for the Iranian university male freshmen. Iranian EFL Journal, 8 (1), 292-300.

[31] Flowerdew, J., \& Miller, L. (2005). Second language listening: Theory and practice. New York, NY: Cambridge University Press.

[32] Gapski, H. (2001). Media literacy: A survey and preliminary considerations of system theoretical framework. Wiesbaden, Germany: Westdeustcher Verlag.

[33] Ghaderpanahi, L. (2012). Using Authentic Aural Materials to Develop Listening Comprehension in the EFL Classroom. English Language Teaching. 5 (6), 146-153.

[34] Ghalami Nobar, A., \& Ahangari, S. (2012). The impact of computer assisted language learning on Iranian EFL learners' task-based listening skill and motivation. Journal of Academic and Applied Studies, 2 (1), 39-61.

[35] Golpour, F. (2014). Critical thinking and EFL learners' performance on different writing modes. Journal of Pan-Pacific Association of Applied Linguistics, 18 (1), 103-119.

[36] Hasan, M., M., and Hoon, T., B. (2013). Podcast applications in language learning: A review

[37] of recent studies. English Language Teaching, 6 (2), 128-135.

[38] Hsu, C.-K., Hwang, G.-J., Chang, Y.-T., \& Chang, C.-K. (2013). Effects of Video Caption Modes on English Listening Comprehension and Vocabulary Acquisition Using Handheld Devices. Educational Technology \& Society, 16 (1), 403-414.

[39] Hayati, A. (2010). The effect of speech rate on listening comprehension of EFL learners. Creative Education, 2, 107-114.

[40] Iimura, H. (2007). The listening process: Effects of types and repetition. Language Education and Technology 44, 75-85. 
Bulletin de la Société Royale des Sciences de Liège, Vol. 86, special edition, 2017, pp. 891 - 907

[41] Ismaili, M. (2013). The effectiveness of using movies in the EFL classroom - A study conducted at South East European University. Academic Journal of Interdisciplinary Studies, 2 (4), 121-132.

[42] Jenkins, H., Purushotma, R., Weigel, M., Clinton, K. \& Robison, A., J. (2009).Confronting the challenges of participatory culture: Media education for the 21st century. The MIT Press Cambridge, Massachusetts London, England.

[43] Karadeniz, A. \& Can, R. (2014). A research on book reading habits and media literacy of students at the faculty of education. Procedia - Social and Behavioral Sciences, 174, $4058-$ 4067.

[44] Kargozari, H., R. \& Tafazoli, D. (2011). Vodcasting: A reusable learning object to teach writing. Presented paper at the 4th international ELT conference on practical aspects of ELT, Turkey, Istanbul.

[45] Karimi, M., \& Biria, R. (2014). The impact of motivating Iranian EFL learners via visuals on their listening comprehension. Theory and Practice in Language Studies, 4 (11), 23222330.

[46] Ketabi, S., Zarei, G., R., \& Khazaie, S. (2011). Mobile mediated versus traditional method of L2 vocabulary learning: A comparison between vocabulary learning with and without pictorial annotation. International Conference on Languages, Literature and Linguistics. PEDR, vol,26 IACSIT Press, Singapore, 26, 117-121.

[47] Khalili Sabet, M., \& Mahsefat, H. (2012). The impact of authentic listening materials on elementary EFL learners' listening skills. International Journal of Applied Linguistics \& English Literature, 1(4), 216-229.

[48] Kilickaya, F. (2004). Authentic materials and cultural content in EFL classrooms. The Internet TESL Journal, 10 (7). Retrieved January 11, 2015 from: http://iteslj.org/Techniques/KilickayaAutenticMaterial.html

[49] Larson, E. (2008). Electronic reading workshop: Beyond books with new literacies and instructional technologies. Jornal of Adolecent and Adult literacy, 52 (2), 121-131.

[50] Lin, T.-B., Li, J.-Y., Deng, F., \& Lee, L. (2013). Understanding New Media Literacy: An Explorative Theoretical Framework. Educational Technology \& Society, 16 (4), 160-170.

[51] Livingstone, S. (2004). What is media literacy? Intermedia, 32 (3), 18-20.

[52] Lynch T. (1998). 'Theoretical perspectives on listening'. Annual Review of Applied Linguistics18, 3-19.

[53] Mahasneh, A. M. (2013). The relationship between multiple intelligence and self-efficacy among sample of Hashemite university students. International Journal of Education and Research, 1 (5), 1-12.

[54] Meihami, H., Meihami, B., Varmaghani, Z. (2013). The Effect of Computer-Assisted Language Learning on Iranian EFL Students Listening Comprehension. International Letters of Social and Humanistic Sciences, 11, 57-65.

[55] Messaris, P. (1998). Visual aspects of media literacy. Journal of Communication, 48(1), $70-80$ 
Bulletin de la Société Royale des Sciences de Liège, Vol. 86, special edition, 2017, pp. 891 - 907

[56] Mishan, F. (2004). Authenticating corpora for language learning: a problem and its resolution. ELT Journal, 58, 219-227.

[57] Nunan D. (1997). Listening in Language Learning. The Language Teacher. The Japan Association of Language Learning, 21 (9), 47-51.

[58] O’Malley, J., Chamot, A., U., \& Kupper, L. (1989). Listening Comprehension Strategies in Second Language Acquisition. Applied Linguistics, 10 (4), 418.

[59] O’Malley, J., \& A. Chamot, A., U. (1990). Learning Strategies in Second Language Acquisition. Cambridge: Cambridge University Press, 1990.

[60] Pintrich, P. R. (2000). The role of goal orientation in self-regulated learning. In M. Boekaerts, P. R. Pintrich, \& M. Zeidner (eds.), Handbook of self-regulation (pp. 451-502). San Diego, CA: Academic Press.

[61] Potter, W., J. (2004a). Argument for the need for a cognitive theory of media literacy.American Behavioral Scientist, 48 (2), 266-272.

[62] Pourhossein Gilakjani, A., \& Ahmadi, M., R. (2011). A study of factors affecting EFL learners' English listening comprehension and the strategies for improvement. Journal of Language Teaching and Research, 2 (5), 977-988.

[63] Pourhosein Gilakjani, A. (2012). The significant role of multimedia in motivating EFL learners' interest in English language learning. I.J. Modern Education and Computer Science, 4, 57-66.

[64] Prensky, M. (2001). Digital Natives, Digital Immigrants. On the Horizon, 9 (5), 1-6.

[65] Richards, J., C. (2001). Curriculum development in language teaching. Cambridge, U.K.: Cambridge University Press.

[66] Rosenbaun, J., E. (2016). Measuring media literacy: Youngsters, television, and democracy. Social Weteschappen, Radbound Uiniversiteit Nijmegen, proefschrfit.

[67] Rost, M. (1994). Introducing listening. London: penguin. Ducation, 5(3), 195-200.

[68] Rost, M. (2011). Teaching and researching listening (2nd Ed.). Harlow, England: Pearson

[69] Rubin, J. (1994). A review of second language listening comprehension research. Modern

[70] Language Journal, 78 (2), 199-221.

[71] Sakai, H. (2009). Effect of repetition of exposure and proficiency level in L2 listening tests. TESOL Quarterly 43, 360-372.

[72] Saran, M., \& Seferoglu, G. (2010). Supporting foreign language vocabulary learning through multimedia messages via mobile phones. Hacettepe University Faculty of Education Journal, 38, 252-266.

[73] Schmidt, H. (2012). Media Literacy Education at the University Level. The Journal of Effective Teaching, 12(1), 2012, 64-77.

[74] Secer, S., Y., E., Sahin, M., \& Alc, B. (2015). Investigating the effect of audio visual materials as warm-up activity in Aviation English courses on students' motivation and participation at high school level. Procedia - Social and Behavioral Sciences, 199, 120 128. 
Bulletin de la Société Royale des Sciences de Liège, Vol. 86, special edition, 2017, pp. 891 - 907

[75] Silverblatt, A. (1995). Media literacy: keys to interpreting media messages. Westport Praeger.

[76] Silviyanti, T., M. (2014). Looking in into EFL Students' Perceptions in Listening by Using English Movie Videos on YouTube. Studies in English Language and Education, 1(1), 45 63.

[77] Solomon, G., \& Schrum, L. (2007). Web 2.0: New tools, new schools. Washington, D., C. International Society for Technology in Education.

[78] Steyaert, J. (2000). Digitale vaardigheden. Geletterdheid in de informatiesamenling. Den Haag: Rathenau Instituut.

[79] Stockwell, G. (2010). Using mobile phones for vocabulary activities: examining the effect of the platform. Language Learning \& Technology, 14 (2), 95-110.

[80] Taghinezhad, A., Tabaeifard, S., \& Bazyar, Z. (2015). Investigating the impact of teaching listening comprehension strategies on the improvement of listening comprehension ability of Iranian EFL learners. International Journal of English Language, Literature and Translation Studies (IJELR), 2 (3), 397-403.

[81] Tarigan, H., G. (1990). Menyimak Sebagai suatu Keterampilan Berbahasa. Bandung: Angkasa

[82] Thoman, E. (2003). Media literacy: A guided tour of the best resources for teaching. The Clearing House, 76 (6), 278-283.

[83] Tyagi, B. (2013). Listening: An important skill and its various aspects. The Criterion an International Journal in English. 12, 1-8.

[84] Underwood, M. (1989). Teaching listening. New York: Longman.

[85] Van Dijk, J. (2005). The deepening divide: inequality in the information society. London: Sage.

[86] Vandergrift, L. (2011). Second language listening. Presage, process, product, and pedagogy. In Hinkel, E. (ed.), Handbook of Research in Second Language Teaching and Learning, 455-471. New York/London: Routledge.

[87] Vandergrift, L., \& Goh, C., C., M. (2012). Teaching and Learning Second Language Listening. Taylor \& Francis group. New York, NY 10017.

[88] Wolvin, A., D., \& Coakley, C., G. (1996). Listening. Boston, MA: McGraw-Hill.

[89] Yavuz, F., Degirmenci, N., Akyuz, S., Y1lmaz, H., \& Celik, O. (2015). Problems and Activities in Listening Skills in EFL Classrooms; from Tradition to a more Comprehensible Input. Procedia - Social and Behavioral Sciences, 197, 930 - 932.

[90] Zarei, A., A., \& Hashemipour, M. (2015). The effect of computer-assisted language instruction on improving EFL learners' autonomy and motivation. Journal of Applied Linguistics, 1 (1), 40-58.

[91] Zhang, L. (2001). Awareness in reading EFL students' metacognitive Knowledge of reading strategies in acquisition-poor Environment. Language Awareness, 10, 268-288. 